\title{
Analisis Pengaruh Citra Merek, Kepercayaan Merek dan Kualitas Produk Terhadap Keputusan Pembelian Sepatu Specs (Studi Kasus Pada Konsumen Sepatu Specs Di Kota Lombok Timur)
}

\author{
Muh Hasban Wadi ${ }^{1 *}$, Muinah Fadhilah ${ }^{2}$, Lusia Tria Hatmanti Hutami ${ }^{3}$ \\ Fakultas Ekonomi Universitas Sarjanawiyata Tamansiswa \\ *Correspondence email: hasbanwadi99@gmail.com,muinahfadhilah17@gmail.com²,trialusia@ustjogja.ac.id ${ }^{3}$
}

\begin{abstract}
Abstrak. Penelitian ini bertujuan untuk mengetahui pengaruh citra merek, kepercayan merek dan kualitas produk dalam memepengaruhi keputusan pembelian konsumen terhadap sepatu olahraga merek specs dan juga untuk mengetahui faktor manakah yang paling besar pengaruhnya terhadap keputusan pembelian konsumen sepatu olahraga merek specs. Penelitian ini mengambil sample 100 orang responden untuk diteliti dengan menggunakan metode Nonprobability Sampling dan dengan menggunakan teknik Insidental Sampling. Analisis data yang digunakan dalam penelitian ini adalah Analisis Regresi Linier Berganda. Sebelum dilakukan analisis regresi ada beberapa tahap pengujian yang dilakukan diantaranya adalah uji validitas dan uji reliabilitas. Kemudian dilakukan uji asumsi klasik diantaranya adalah uji normalitas, uji multiokolonieritas, uji heteroskedastisitas, uji signifikansi parameter individu (uji-t), uji signifikansi simultan (uji-F) dan uji koefisien determinasi $\left(\mathrm{R}^{2}\right)$.
\end{abstract}

Kata Kunci : Citra Merek; Kepercayan Merek; Kualitas Produk; Keputusan Pembelian

\begin{abstract}
This study aims to determine the effect of brand image, brand trust and product quality in influencing consumer purchasing decisions of specs brand sport shoes and also to determine wich factors have the greatest influence on consumer purchasing decisions of specs brand sports shoes. The study took a sample of 100 respondents to be examined using nonprobability sampling method and by using the incidental sampling technique. The data analisys used in this research is Multiple Linier Regression Analysis. Before the regression analysis was carried out, there were several stages of testing which were carried out, including the validity test and the reliability test. Then the classical assumption tests were carried out including normality test, multicolonierity test, heteroskedastisity test, individual parameter significance test (t-test), simultaneous significance test (F-test) and determination coefficient test $\left(R^{2}\right)$.
\end{abstract}

Keywords : Brand Image; Brand Trust; Product Quality; Purchase Decisions

\section{Pendahuluan}

Pada era globalisasi sekarang persaingan dalam dunia bisnis semakin ketat, seiring dengan berkembangnya teknologi yang semaki canggih, perusahaan harus mampu menghasilkan produk-produk yang berkualitas agar mampu bersaing, salah satu persaingan bisnis yang ketat sekarang adalah bisnis dalam bidang olahraga. Di zaman modern sekarang olahraga sudah menjadi kebutuhan yang yang penting bagi setiap individu, karena dengan berolahraga dapat menjaga tubuh agar tetap sehat dan juga dengan berolahraga dapat mengurangi resiko terkena berbagai macam penyakit yang dapat menghambat aktivitas sehari-hari, olahraga juga menjadi alasan masyarakat untuk menghabiskan waktu luangnya ditengah kesibukannya terkait dengan hobi berolahraganya. Perusahaan pada dasarnya ingin menjadi pemimpin pasar pada persaingan yang dihadapi dalam dunia bisnis.. Agar dapat menjadi pemimpin pasar perjuangan yang dilakukan perusahaan tidak mudah dalam memenangkan persaingan bisnis sehingga mampu menguasai pangsa pasar yang besar dengan produk yang sfesifik, hasil yang inovasi dan kreatif yang membuat konsumen tertarik dengan preoduk yang ditawarkan sehingga dapat menguasai pasar dengan produk yang berkualitas. Perusahaan yang cerdas berusaha untuk memahami proses keputusan pembelian konsumen secara penuh, semua pengalaman mereka dalam pembelajaran, memilih, menggunakan, dan bahkan menyingkirkan produk (Kotler, 2011 dalam Farhan, 2015). Memahami keinginan para konsumen dalam produk yang diinginkannya merupakan hal yang sangat penting dan telah menjadi perhatian pada berbagai industry, termasuk pada industry olahraga. Sekarang olahraga suadah menjadi suatu kegiatan yang banyak diminati oleh masyarakat dunia dan Indonesia. Meningkatnya minat dan kesadaran masyarakat tentang berolahraga diiringi dengan berkembangnya pusat-pusat arena olahraga yang semakin canggih dan modern seperti lapangan futsal, lapangan sepakbola, lapangan bulu tangkis, jogging track, gym, lapangan golf, lapangan tenis, dan masih banyak lagi arena olahraga yang lainnya. Dalam berolahraga tentunya membutuhkan alat untuk menunjang kegiatan berolahraga berupa sepatu. Untuk memenuhi kebutuhan olahraga masyarakat tertunya harus didukung dengan sepatu yang berkualitas dan tepat agar dapat meningkatkan performa semakin baik dan nyaman saat berolahraga.

Beberapa perusahaan besar yang memproduksi sepatu olahraga seperti Nike, Adidas, Puma, Reebok, New Balance, Specs, Diadora, Ardiles, dan Ortuseight. Mereka merupakan perusahaan sepatu besar yang memproduksi sepatu olahraga dan sudah memiliki pangsa pasar yang besar. Dari perusahaan sepatu tersebut Specs merupakan 
perusahaan lokal asli buatan Indonesia yang menantang produk buatan luar negeri seperti Nike, Adidas, Puma, Reebook, dan New Balance. Dengan banyaknya pilihan merek yang ada tentunnya dalam hal ini citra merek, kepercayan merek dan kualitas produk sangat sangat penting bagi para konsumen untuk menentukan keputusan dalam pembelian suatu produk. Sejak awal berdirinya brand Specs merupakan brand kelas bawah yang belum dikenal oleh masyarakat. Specs yang semakin giat dalam membuat inovasi terbaru dengan menghasilakan produk yang berkualitas dengan harga yang relatif murah membuat brand specs mulai dikenal oleh masyarakat. Produk sepatu olahraga yang dibuat specs memiliki kualitas yang bagus dan mampu bersaing dengan brand luar negeri yang sudah memiliki pangsa pasar yang besar. Dengan kemajuan teknologi yang semakin berkembang Specs mampu bersaing dengan beberapa brand ternama yang sudah memiliki pangsa pasar yang luas. Dengan produk yang berkualitas, harga yang lebih murah dengan produk buatan luar negeri, varian model yang menarik yang disesuaikan dengan model yang menarik dan modern dengan kombinasi warna yang menarik yang melengkapi tampilan sepatu sehingga para penggunanya merasa nyaman dan tampil lebih percaya diri saat tampil dilapangan membuat brand Specs semakin banyak diminati di pasar indonesia. Variasi harga yang ditawarkan Specs juga lebih murah dan kualitas produk yang ditawarkan seimbang dengan kulitas produk yang ditawarkan brand luar negeri yang sudah memimiliki pangsa pasar yang besar seperti Nike, Puma, Reebok, New Balance dan Adidas. Kualitas produk yang didapatkan konsumen Specs juga tidak jauh beda dengan kualitas produk yang didapatkan konsumen Nike, Puma, Reebok, New Balance dan Adidas dengan harga yang lebih terjangkau. Specs merupakan produk lokal asli buatan Indonesia yang mampu menyaingi produk luar negeri yang sudah mendunia seperti Nike, Puma, Reebook, New Balance dan Adidas. Hingga sekarang produk speecs terus berkembang dan sangat popular dan banyak diminati di pasar Indonesia dengan pengalamannya membuat produk sepatu olahraga dengan menggunakan teknologi yang modern untuk meningkatkan kualitas produknya.

Tujuan penelitian ini adalah menganalisis faktor-faktor apa saja menpengaruhi keputusan pembelian sepatu olahraga merek Specs yang meliputi citra merek, kepercayaan merek, dan kualitas produk studi kasus pada konsumen sepatu merek specs di kota Lombok Timur.

\section{Kajian Teoritis \\ Citra Merek}

Menurut Hedman \& Orrensalo (2018) dalam Jayanti \& Putri (2019) "The image is the foundation of the brand, it is therefore importand for companies to attach relevant characteristic to the brand image in order to shape $i$, in summary, brand image, reflect the strength and assence of the brand". Citra merupakan dasar dari sebuah merek, oleh sebab itu penting bagi perusahan unmtuk memiliki karakteristik yang relevan dengan citra merek untuk membentuknya. Citra merek adalah ingatan yang berasal dalam pikiran seseorang tentang suatu barang yang bersifat positif positif maupun bersifat negatif. Jika merek yang terdapat bersifat posistif maka konsumen lebih yakin terhadap produk tersebut dan memeberikan manfaat yang lebih bagi konsumen karena produk tersebut sudah dikenal oleh masyarakat, dan begitupun sebaliknya jika merek yang terdapat bersifat negatif maka konsumen tidak percaya pada barang tersebut dan pembeli akan mempertimbangklan jika ingin membeli produk tersebut (Ghifani \& Syahputra, 2017 dalam Veronika \& 2Hikmah, 2020).

\section{Kepercayaan Merek}

Kepercayaan merek adalah kemampuan merek untuk dipercaya yang bersumber pada keyakinan konsumen bahwa produk tersebut mampu memenuhi nilai yang dijanjikan dan intensi baik merek yang didasarkan pada keyakinan konsumen bahwa merek tersebut mampu mengutamakan kepentingan konsumen (Sutarso \& Suyanto, 2019). Kepercayaan merek adalah kehandalan dari sudut pandang pelanggan didasarkan pada pengalaman, atau lebih padaurutan-urutan transaksi yang dicirikan oleh terpenuhinya harapan akan kinerja produk dan kepuasan (Kustini, 2011 dalam (Sutarso \& Suyanto, 2019).

\section{Indikator Kepercayaan Merek}

Menurut R.Lassoued dan J.E.Hobbs (2015) dalam Trista, Prihatini \& Saryadi (2020) terdapat 4 indikator kepercayaan merek yaitu :

1. Kredibilitas merupakan sebagian tingkat kepercayan informasi produk yang terkandung dalam merek yang diharapakan dapat meningkatkan persepsi kualitas dan nilai merek.

2. Kompetensi merek dapat dikembangakan melalui penggunakaan langsung atau dari mulut ke mulut. Dan kompetensi merek dapat dilihat ketika konsumen merasakan bahkualitas produk atau jasa yang ditawarkan sesuai dengan kebutuhannya.

3. Kebaikan merek mencerminkan niat suatu perusahan terhadap konsumen. Niat tersebut dapat berupa manfat (kesehatan, social, lingkungan ) jika memebeli atau mengkonsumsi produk perusahaan. 
4. Reputasi merek meliputi keyakinan yang ada dalam bentuk konsumen bahwa merek akan konsisten dalam memberikan produk dengan kualitas tinggi, yang tercermin dalam kesediaan konsumen untuk membayardengan harga yang lebih mahal.

\section{Kualitas Produk}

Kualitas produk menjadi fator utama yang di nilai oleh para konsumen sebelum membeli suatu produk, produk yang memiliki kualitas yang bagus tentunya akan meningkatkan pembelian produk tersebut. Kualitas produk juga merupakan alat yang di gunakan oleh para pemasar untuk menentukan positioning produknya di pasar. Perusahaan harus memiliki kualitas produk yang baik untuk membantu dan menunjang produknya agar tetap laris dipasaran. Menurut Kotler, Philip, \& Amstrong (2012) dalam Tazkiyatunnisa (2019) kualitas produk merupakan sebuah karakteristik dari suatu produk atau jasa demi menunjang kemampuannya dalam memuaskan konsumen. Sedangkan menurut Kotler dan Amstrong (2014) dalam Bahar (2019) "The characteristics of a product of service that bear on its ability to satisfy stated or implied customer need" yang artinya kualitas produk adalah karakteristik dari produk dan jasa yang menjunjung kemampuannya untuk memuaskan kebutuhan konsumen. Kualitas produk adalah kemampuan produk untuk menjalankan tugasnya yang mencakup daya tahan, kehandalan atau kemajuan, kekuatan, kemudahan dalam pengemasan dan reparasi produk dan ciri-ciri lainnya (Sundalangi, 2014 dalam Ratnasih \& Nurjanah, 2019).

\section{Mengukur Kualitas Produk}

Menurut Tjiptono (2012) dalam Fitriah \& Budiyanto (2020) ada delapan cara mengukur kualitas produk diantaranya adalah sebagai berikut : 1) Kinerja (Performance); 2) Fitur (Feature); 3) Realibilitas; 4) Konformasi (Conformance); 5) Daya Tahan (Durability); 6) Service Ability; dan 7) Estetika (esthetic)

\section{Keputusan Pembelian}

Menurut Kotler, Phillip, \& Amstrong (2016) dalam Tazkiyatunnisa (2019) mendefinisikan keputusan pemebelian adalah bagian dari perilaku konsumen tentang bagaimana individu, kelompok, dan organisasi memilih, membeli, menggunakan, serta bagaimana barang, jasa, ide atau pengalaman untuk memuaskan kebutuhan dan keinginan mereka. Keputusan pembelian adalah suatu keputusan yang dikerjakan bagi seseorang dalam bentuk keinginan dan kebutuhan dari suatu barang yang bisa dipengaruhi oleh budaya, keluarga, maupun lingkungan yang akan memepengaruhi diri sendiri saat menunaikan belanja suatu barang dalam bentuk barang ataupun jasa (Merentek, 2017 dalam Veronika \& 2Hikmah, 2020).

\section{Mengukur Keputusan Pembelian}

Menurut Tjiptono (2012) dalam Iriani \& Indriyani (2019) ada 5 cara mengukur keputusan pembelian, tterdiri dari : pilihan produk, pilihan merek, pilihan penyalur, waktu pembelian, jumlah pembelian

\section{Metode}

Berdasarkan sifatnya, penelitian ini dapat dikategorikan kedalam pendekatan kuantitatif. Penelitian ini di kategorikan dalam pendekatan kuantitatif karena data pada penelitian ini berupa angka-angka dan analisis menggunakan statistik. Variabel dalam penelitian ini terdiri dari variabel independen berupa citra merek, kepercayaan merek, dan kualitas produk. Sedangkan variabel dependennya adalah keputusan pembelian. Sumber data dalam penelitian ini berupa data primer berbentuk kuesioner yang disebarkan kepada konsumen sepatu olahraga merek Specs di kota Lombok Timur. Sedangkan data sekundernya bersumber dari literatur seperti jurnal, buku, karya ilmiah, dan sumber-sumber lainnya yang relevan dengan penelitian ini. Metode pengumpulan data pada penelitian ini dengan kuesioner dan studi pustaka. Penelitian ini dilakukan pada konsumen sepatu olaharaga merek Specs di kota Lombok Timur. Waktu pengambilan data dalam penelitian ini dilakukan dalam jangka waktu kurang lebih selama satu hingga dua bulan dimulai dari bulan Januari sampai Februari 2021.

Populasi adalah wilayah generalisasi yamg terdiri atas : obyek/obyek yang mempunyai kuantitas dan karakteristik tertentu yang ditetapkan oleh peneliti untuk dipelajari dan kemudian ditarik kesimpulannya (Sugiyono, 2018). Populasi yang digunakan dalam penelitian ini adalah konsumen sepatu olahraga merek specs di kota Lombok Timur. Sample adalah bagian dari jumlah dan karakteristik yang dimiliki oleh populasi tersebut (Sugiyono : 2018). Teknik pengambilan sample pada penelitian ini adalah dengan menggunakan teknik Nonprobability Sampling dengan pendekatan Insidental Sampling yaitu teknik penentuan sampel berdasarkan kebetulan, yaitu siapa saja yang secara kebetulan/insidensial bertemu dengan peneliti dapat digunakan sebagai sample, bila dipandang orang yang kebetulan ditemui itu cocok sebagai msumber data (Sugiyono, 2018). 
Data sekunder dalam penelitian ini bersumber dari literatur seperti jurnal, buku, karya ilmiah, dan sumbersumber lainnya yang relevan dengan penelitian ini.

\section{Metode Pengambilan Data}

a. Kuesioner, merupakan teknik pengumpulan data yang dilakukan dengan cara memberi seperangkat pertanyaan atau pernyataan tertulis kepada responden untuk dijawab (Sugiyono : 2011). Kuesioner merupakan teknik pengumpulan data yang efisien biloa peneliti tahu dengan pasti variabel yang akan diukur dan tahu apa yang bisa diharapkan dari responden. Kuesioner juga sangat cocok digunakan bila jumlah responden cukup besar dan tersebar di wilayah yang luas. Kuesioner dapat berupa pertanyaan / pernyataan tertutup atau terbuka yang dapat diberikan kepada responden secara langsung atau dikirim melalui pos dan internet (Sugiyono, 2018). Dalam penelitian ini kuesioner yang di sebarkan berupa pertanyaan/pernyataan yang berkaitan dengan cittra merek, kepercayaan merek, dan kualitas produk terhadap keputusan pembelian.

b. Penelitian Pustaka (Library Research), yaitu pengumpulan data secara teoritis dengan cara menelaah berbagai buku dan literatur dan sumber-sumber lainnya yang berkaitan dengan masalah yang dibahas dalam penelitian ini.

\section{Uji Validitas}

Uji validitas dilakukan untuk menguji apakah data yang didapatkan dalam kuesioner valid atau tidak. Kuesioner dikatan valid apabila instrument mampu mengungkapkan data dari variabel yang diteliti. Menurut Sugiyono (2017) dalam Tazkiyatunnisa (2019) validitas menunjukan derajat ketepatan antara data yang sesungguhnya terjadi pada objek dengan data yang dikumpulkan oleh peneliti. Untuk mengetahui validitas sebuah item, yang dilakukan adalah dengan mengkorelasikan skor item dengan total item-item tersebut. Apabila koefisien antara item dengan total item korelasinya diatas 0.5 maka item tersebut dinyatakan valid, namun jika nilai korelasinya dibawah 0.5 maka item tersebut dinyatakan tidak valid.

\section{Uji Reliabilitas}

Uji reliabilitas dilakukan untuk mengukur seberapa konsisten hasil pengukuran jika dilakukan pengukuran berulang dua kali atau lebih dengan menggunakan alat ukur yang sama. Dalam penelitian ini, uji reliabilitas dilakukan dengan cara melihat nilai cronbach alpha $(\alpha)$. Suatu variabel dikatakan reliabel apabila nilai dari cronbch alpha $(\alpha)>$ 0,6 . Sebaliknya apabila nilai dari cronbach alpha $(\alpha)<0,6$ maka variabel tersebut dikatakan tidak reliabel.

\section{Teknik Analisis Data}

a. Analisis Deskriptif, merupakan statistik yang digunakan untuk menganalisis data dengan cara mendeskripsikan atau menggambarkan data yang telah terkumpul sebagaimana adanya tanpa bermaksud membuat kesimpulan yang berlaku untuk umum atau generalisasi (Sugiyono, 2018). Metode ini bertujuan untuk mengolah data mentah menjadi bentuk yang mudah dipahami dengan cara mendeskrifsikan atau menggambarkan data yang sudah terkumpul kemudian diolah menggunakan program softwer SPSS for windows.

b. Analisis Regresi Linier Berganda, bertujuan untuk menguji seberapa besar pengaruh citra merek (X1), kepercayaan merek (X2), dan kualitas produk (X3) terhadap keputusan pembelian (Y) pada sepatu merek specs di kota Lombok Timur. Adapun bentuk rumus regresi linier berganda pada penelitian ini di rumuskan sebagai berikut :

$Y=a+\beta_{1} X_{1}+\beta_{2} X_{2}+\beta_{3} X_{3}+e$

Keterangan : Y: Keputusan Pembelian; a : Konstanta; $\beta_{1}$ : Koefisisen regresi variabel citra merek; $\beta_{2}$ : Koefisisen regresi variabel kepercayaan merek; $\beta_{3}$ : Koefisien regresi variabel kualitas produk; $\mathrm{X}_{1}$ : Citra Merek; $\mathrm{X}_{2}$ : Kepercayaan Merek; $\mathrm{X}_{3}$ : Kualitas Produk; E: Error

\section{Uji Asumsi Klasik \\ Uji Normalitas}

Uji normalitas bertujuan untuk menguji apakah data yang akan diguanakan dalam model regresi berdistribusi normal atau tidak. Jika suatu variabel berdistribisi dengan baik, maka hasil uji statistik dikatakan baik. Begitu juga sebaliknya jika suatu variabel tidak berdistribusi normal, maka hasil uji statistik mengalami penurunan. Dasar pengambilan keputusan yang digunakan untuk uji normalitas adalah sebagai berikut:

1. Apabila grafik histogram menunjukkan pola distribusi normal atau jika garis meyebar disekitar garis diagonal dan mengikuti arah garis diagonal, maka dapat dikatan bahwa model regresi memenuhi asumsi normalitas.

2. Apabila grafik histogram tidak menunjukkan pola distribusi normal atau jika data menyebar jauh dari diagonal dan tidak mengikuti arah garis diagonal, maka dapat dikatakan bahwa model regresi tidak memenuhi asumsi normalitas. 


\section{Uji Multikolonieritas}

Uji multikolonieritas pada dasarnya bertujuan untuk menguji apakah ditemukannya korelasi antar variabel pada model regresi. Model regresi dapat dikatakan baik apabila tidak terjadi korelasi diantara variabel bebas. Dasar pengambilan keptusan yang digunakan untuk menentukan multiolonieritas adalah sebagai berikut :

1. Apabila nilai Variance Inflation Factor (VIF) $>10$ dan nilai tolerance $<0.1$, maka terjadi masalah multikolonieritas

2. Apabila nilai Variance Inflation Factor $(\mathrm{VIF})<10$ dan nilai tolerance $>0.1$, maka tidak terjadi masalah multikolonieritas.

\section{Uji Heteroskedastisitas}

Uji heteroskedastisitas bertujuan untuk menguji apakah dalam model regresi terjadi ketidaksamaan variance dari residual satu pengamatan ke pengamatan yang lain. Pengujian di lakukan dengan metode informal atau metode grafik scatterplot. Untuk mengetahui ada atau tidaknya heteroskedastiositas adalah dengan cara melihat grafik plots ZPRED (Nilai prediksi variabel dependen) dengan residual SRESID. Pengujian menggunakan SPSS menunjukkan hasil bahwa dalam model regresi dikatakan tidak terjadi heteroskedastisitas apabila titik-titik menyebar secara acak diatas angka 0 pada sumbu Y. Dasar pengambilan keputusan yang digunakan untuk menentukan heteroskedastisitas adalah sebagai berikut:

1. Jika ada pola tertentu seperti titik-titik yang membentuk pola tertentu yang teratur maka telah terjadi heteroskedastisitas.

2. Jika tidak ada pola yang jelas seperti titi-titik yang menyebar ke atas dan di bawah angka 0 pada sumbu, maka tidak terjadi heteroskedastisitas.

\section{Uji Hipotesis}

\section{Uji Signifikansi Parameter Individu $(U j i-t)$}

Uji t pada dasarnya digunakan untuk mengetahui seberapa besar pengaruh variabel independen secara individu terhadap variabel dependen. Pengujian ini dilakukan untuk megetahui seberapa besar pengaruh variabel independen citra merek, kepercayan merek, dan kualitas produk dalam mempengaruhi keputusan pembelian konsumen secara terpisah, dengan tingkat signifikan 5\% $(\alpha=0.05)$. Kriteria pengambilan keputusannya adalah sebagai berikut:

1. Apabila $\mathrm{t}$ - hitung $>\mathrm{t}$ - tabel, maka variabel independen memiliki hubungan yang signifikan terhadap variabel dependen, artinya Ho ditolak dan Ha diterima

2. Apabila $\mathrm{t}$ - hitung $<\mathrm{t}$ - tabel, maka variabel independen tidak memiliki hubungan yang signifikan terhadap variabel dependen, artinya Ho diterima dan Ha ditolak.

\section{Uji Signifikansi Simultan (Uji - F)}

Uji signifikansi simultan digunakan untuk mengetahui seberapa besar pengaruh variabel independen secara bersama-sama dalam mempengaruhi variabel dependen. Pengujian ini dilakukan untuk mengetahu seberapa besar pengaruh variabel independen citra merek, keprcayan merek, dan kualitas produk dalam mempengaruhi keputusan pembelian konsumen secara simultan atau bersama-sama, dengan tingkat signifikan 5\% $(\alpha=0.05)$. Menurut Ghozali (2018) Kriteria pengambilan keputusannya adalah sebagai berikut :

1. Apabila F- hitung > F- tabel, maka variabel independen memiliki pengaruh signifikan terhadap variabel dependen, artinya Ha diterima dan Ho ditolak

2. Apabila F- hitung $<$ F- tabel, maka variabel independen tidak memiliki pengaruh signifikan terhadap variabel dependen, artinya Ha ditolak dan Ho diterima.

\section{Uji Koefisien Determinasi $\left(R^{2}\right)$}

Uji koefisien determinasi digunakan untuk mengukur seberapa jauh variabel independen dalam menerangkan variasi variabel dependen. Nilai dari koefisien determinasi adalah antara 0.1 hingga 1 . Menurut Ghozali (2018) Apabila koefisien determinasi $\left(\mathrm{R}^{2}\right)$ akan mendekati angka 1 maka dapat dikatakan semakin kuat model tersebut menerangkan hubungan variabel bebas (independen) terhadap variabel terikat (dependen). Sebaliknya jika koefisisen determinasi $\left(\mathrm{R}^{2}\right)$ mendekati angka 0 maka dapat dikatakan lemah pengaruh variabel bebas (independen) terhadap variabel terikat (dependen). Dalam penelitian ini koefisien determinasi yang digunakan adalah R square . 
Muh Hasban Wadi, Muinah Fadhilah dan Lusia Tria Hatmanti Hutami, Analisis Pengaruh Citra Merek, Kepercayaan Merek dan Kualitas Produk Terhadap Keputusan Pembelian Sepatu Specs (Studi Kasus Pada Konsumen Sepatu Specs Di Kota Lombok Timur)

\section{Hasil}

Tabel 1.

Hasil Uji Validitas

\begin{tabular}{|c|c|c|c|c|}
\hline Variabel & Item & Corrected item - Total Correlation & Stand ar Validitas & Keterangan \\
\hline \multirow{5}{*}{ Citra Merek ( X1) } & $\mathrm{X} 1.1$ & 0.689 & 0.5 & Valid \\
\hline & $\mathrm{X} 1.2$ & 0.537 & 0.5 & Valid \\
\hline & $\mathrm{X} 1.3$ & 0.660 & 0.5 & Valid \\
\hline & $\mathrm{X} 1.4$ & 0.713 & 0.5 & Valid \\
\hline & $\mathrm{X} 1.5$ & 0.587 & 0.5 & Valid \\
\hline \multirow[t]{6}{*}{ Kepercayaan Merek ( X2 ) } & $\mathrm{X} 2.1$ & 0.634 & 0.5 & Valid \\
\hline & $\mathrm{X} 2.2$ & 0.675 & 0.5 & Valid \\
\hline & $\mathrm{X} 2.3$ & 0.519 & 0.5 & Valid \\
\hline & $\mathrm{X} 2.4$ & 0.748 & 0.5 & Valid \\
\hline & $\mathrm{X} 2.5$ & 0.711 & 0.5 & Valid \\
\hline & $\mathrm{X} 2.6$ & 0.760 & 0.5 & Valid \\
\hline \multirow[t]{5}{*}{ Kualitas Produk ( X3 ) } & $\mathrm{X} 3.1$ & 0.667 & 0.5 & Valid \\
\hline & $\mathrm{X} 3.2$ & 0.673 & 0.5 & Valid \\
\hline & $\mathrm{X} 3.3$ & 0.681 & 0.5 & Valid \\
\hline & $\mathrm{X} 3.4$ & 0.671 & 0.5 & Valid \\
\hline & $\mathrm{X} 3.5$ & 0.695 & 0.5 & Valid \\
\hline \multirow[t]{6}{*}{ Keputusan Pembelian (Y ) } & Y.1 & 0.681 & 0.5 & Valid \\
\hline & $\mathrm{Y} .2$ & 0.691 & 0.5 & Valid \\
\hline & Y. 3 & 0.725 & 0.5 & Valid \\
\hline & Y.4 & 0.705 & 0.5 & Valid \\
\hline & Y.5 & 0.671 & 0.5 & Valid \\
\hline & Y.6 & 0.675 & 0.5 & Valid \\
\hline
\end{tabular}

Sumber : Data Olahan

Data tabel diatas dapat di ambil kesimpulan bahwa datakuesioner dalam penelitian ini dikatan valid. Dimana dari data diatas di paparkan bahwa nilai korelasi dari masing-masing item lebih dari 0.5. karena suatu item dikatakan valid apalila nilai korelasinya lebih dari 0.5 . sebaliknya apabila nilai korelasinya dibawah 0.5 maka item tersebut dikatakan tidak valid. Dalam penelitian ini dapat disimpulkan bahwa semua item dinyatakan valid karena memiliki nilai korelasi lebih dari 0.5 .

Tabel 2 dijelaskan bahwa semua item memiliki nilai Cronbah's Alpha If Item Deleted $>0.60$. untuk itu data kuesioner dalam penelitian ini dapat dikatan reliable atau handal untuk digunakan sebagai alat ukur dalam penelitian ini.

Tabel 2.

Hasil Uji Reliabilitas

\begin{tabular}{|c|c|c|c|c|}
\hline Variabel & Item & Cronbach's Alpha If Item Deleted & Standar Reliabilit as & Keterangan \\
\hline \multirow{5}{*}{ Citra Merek (X1) } & $\mathrm{X} 1.1$ & 0.763 & 0.60 & Reliabel \\
\hline & $\mathrm{X} 1.2$ & 0.807 & 0.60 & Reliable \\
\hline & $\mathrm{X} 1.3$ & 0.770 & 0.60 & Reliable \\
\hline & $\mathrm{X} 1.4$ & 0.749 & 0.60 & Reliable \\
\hline & $\mathrm{X} 1.5$ & 0.818 & 0.60 & Reliable \\
\hline \multirow[t]{6}{*}{ Kepercayaan Merek (X2) } & $\mathrm{X} 2.1$ & 0.852 & 0.60 & Reliable \\
\hline & $\mathrm{X} 2.2$ & 0.846 & 0.60 & Reliable \\
\hline & $\mathrm{X} 2.3$ & 0.876 & 0.60 & Reliable \\
\hline & $\mathrm{X} 2.4$ & 0.832 & 0.60 & Reliable \\
\hline & $\mathrm{X} 2.5$ & 0.839 & 0.60 & Reliable \\
\hline & $\mathrm{X} 2.6$ & 0.832 & 0.60 & Reliable \\
\hline \multirow[t]{5}{*}{ Kualitas Produk (X3) } & $\mathrm{X} 3.1$ & 0.833 & 0.60 & Reliable \\
\hline & $\mathrm{X} 3.2$ & 0.832 & 0.60 & Reliable \\
\hline & $\mathrm{X} 3.3$ & 0.830 & 0.60 & Reliable \\
\hline & $\mathrm{X} 3.4$ & 0.832 & 0.60 & Reliable \\
\hline & $\mathrm{X} 3.5$ & 0.826 & 0.60 & Reliable \\
\hline \multirow[t]{6}{*}{ Keputusan Pembelian (Y) } & Y. 1 & 0.863 & 0.60 & Reliable \\
\hline & Y.2 & 0.861 & 0.60 & Reliable \\
\hline & Y.3 & 0.856 & 0.60 & Reliable \\
\hline & Y.4 & 0.859 & 0.60 & Reliable \\
\hline & Y.5 & 0.864 & 0.60 & Reliable \\
\hline & Y.6 & 0.864 & 0.60 & Reliable \\
\hline
\end{tabular}

Sumber : Data Olahan

Tabel 3.

Hasil Analisis Regresi Linier Berganda

\begin{tabular}{|c|c|c|c|c|c|}
\hline \multirow[b]{2}{*}{ Model } & \multicolumn{2}{|c|}{ Unstandardized Coefficients } & \multirow{2}{*}{$\begin{array}{c}\text { Standardized Coefficients } \\
\text { Beta }\end{array}$} & \multirow[b]{2}{*}{$t$} & \multirow[b]{2}{*}{ Sig. } \\
\hline & $\mathrm{B}$ & Std. Error & & & \\
\hline $\begin{array}{ll}1 & \text { (Constant) }\end{array}$ & 3.244 & 1.305 & & 2.486 & 6.015 \\
\hline $\mathrm{x} 1$ & .218 & .096 & .1 & 2.280 & 0.025 \\
\hline $\mathrm{x} 2$ & .207 & .100 & .2 & 2.071 & 1.041 \\
\hline $\mathrm{x} 3$ & .603 & .115 & .5 & 5.232 & 2.000 \\
\hline
\end{tabular}

Sumber : Data Olahan

Berdasrkan datatabel diatas didapat persamaan regresi linier berganda sebagai berikut : $\mathrm{Y}=0.188 \mathrm{X} 1+0.216 \mathrm{X} 2+0.525 \mathrm{X} 3$

Nilai 0,188 pada variabel citra merek (X1) adalah bernilai positif sehingga semakin tinggi citra merek maka akan semakin tinggi keputusan pembelian konsumen dalam membeli sepatu olahraga merek specs. Koefisien regresi 0,188 menyatakan bahwa setiap penambahan citra merek sebesar $100 \%$ maka akan meningkatkan keputusan 
pembelian sebesar 0.188 dengan asumsi variabel lain bernilai tetap. Sehingga dapat dikatak bahwa variabel citra merek berpengaruh positif dan signifikan terhadap keputusan pembelian sepatu olahraga merek specs. Nilai 0,216 pada variabel kepercayaan merek ( X2) adalah bernilai positif sehingga semakin tinggi kepercayaan merek akan semakin tinggi juga keputusan pembelian sepatu olahraga merek specs. Koefisien 0,216 menyatakan bahwa setiap penambahan $100 \%$ kepercayaan merek akan meningkatkan keputuasan pembelian konsumen terhadapat sepatu olahrga merek specs sebesar 0,216 dengan asumsi variabel lain berniali tetap. Sehingga dapat dikatakan bahwa variabel kepercayaan merek berpengaruh positif dan signifikan terhadap keputusan pembelian sepatu olahraga merek specs. Nilai 0.525 pada variabel kualitas produk (X3) adalah positif sehingga semakin tinggi kualitas produk maka akan meningkatkan keputusan pembelian konsumen terhadap keputusan pembelian sepatu olaharaga mere kspecs. Koefisien 0.525 menyatakan bahwa setiap penambahan $100 \%$ kualitas produk akan meningkatkan keputusan pembelian konsumen sepatu olahraga merek specs sebesar 0.525 dengan asumsi variabel lain bernilai tetap.sehingga dapat dikatakan bahwa kualitasa produk berpengaruh positif dan sisgnifikan terhadap keputusan pembelian sepatu oahraga merek specs.

\section{Gambar 1}

\section{Hasil Uji Normalitas}

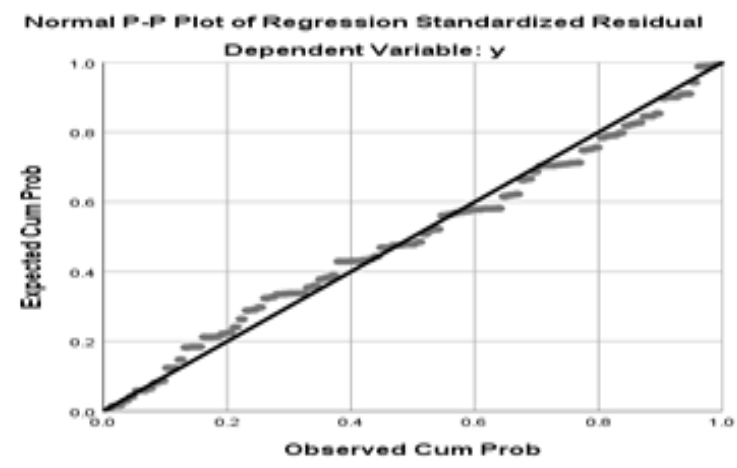

Sumber : Data Olahan

Berdasarkan tabel uji normalitas di atas menggunakan SPSS menggambarkan bahwa garis ploting (titik-titik) mengikuti garis diagonal, sehingga dapat dikatakan bahwa model regresi memenuhi asumsi normalitas.

Tabel 4

Hasil Uji Multikolonieritas

\begin{tabular}{|c|c|c|c|c|c|c|c|}
\hline \multirow[b]{2}{*}{ Model } & \multicolumn{2}{|c|}{ Unstandardized Coefficients } & \multirow{2}{*}{$\begin{array}{c}\text { Standardized Coefficients } \\
\text { Beta }\end{array}$} & \multirow{3}{*}{$\begin{array}{c}\mathrm{t} \\
2.486\end{array}$} & \multicolumn{2}{|c|}{ Collinearity Statistics } & \multirow[b]{2}{*}{ VIF } \\
\hline & B & Std. Error & & & Sig. & Tolerance & \\
\hline 1 (Constant) & 3.244 & 1.305 & & & .015 & & \\
\hline $\mathrm{x} 1$ & .218 & .096 & .188 & 2.280 & .025 & .350 & 2.860 \\
\hline $\mathrm{x} 2$ & .207 & .100 & .216 & 2.071 & .041 & .219 & 4.568 \\
\hline $\mathrm{x} 3$ & .603 & .115 & .525 & 5.232 & .000 & .237 & 4.217 \\
\hline
\end{tabular}

Sumber : Data Olahan

Beradasarkan data tabel diatas menunjukan bahwa :

1. Nilai tolerance X1 adalah $0,350>0,100$ dan nilai VIF adalah $2.860<10,00$ maka dapat disimpulkan tidak ada gejala multikolinearitas.

2. Nilai tolerance $\mathrm{X} 2$ adalah $0,219>0,100$ dan nilai VIF adalah $4.568<10,00$ maka dapat disimpulkan tidak ada gejala multikolinearitas.

3. Nilai tolerance X3 adalah 0,237 >0,100 dan nilai VIF adalah $4.217<10,00$ maka dapat disimpulkan tidak ada gejala multikolinearitas.

Berdasarkan data diatas dapat di simpulkan bahwa pada variabel X1, X2, dan X3 tidak terdapat gejala multikolonieritas, sehingga model regresi dalam penelitian ini dikatakan baik karena tidak terdapat gejala multikolonieritas. 


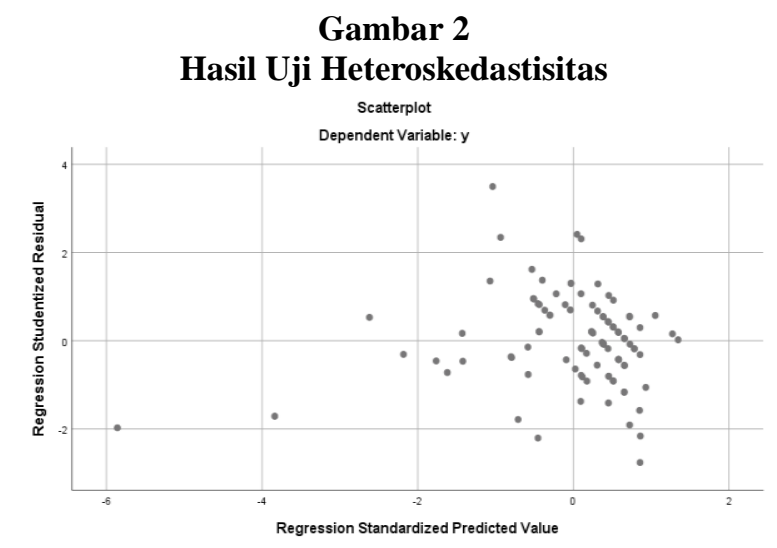

Sumber : Data Olahan

Berdasarkan data tabel di atas menunjukan bahwa tidak ada pola yang jelas yang menyebar ke atas dan di bawah angka 0 pada sumbu Y. titik - titik menyebar secara acak dibawah angka 0 pada sumbu Y, sehingga dapat dikatakan bahwa tidak ada gejala heteroskedastisitas.

Uji $t$

Pengujian Hipotesis Pertama (H1) Pengaruh Citra Merek Terhadap Keputusan Pembelian

Diketahui nilai sig. untuk pengaruh X1 terhadap Y adalah sebesar $0.025<0.05$ dan nilai t- hitung $2.280>$ ttabel 1.985, sehingga dapat disimpulkan bahwa H1 dapat diterima dan H0 ditolak. Sehingga dapat disimpulkan bahwa variabel Citra Merek memiliki pengaruh yang positif dan signifikan terhadap keputusan pembelian konsumen.

Pengujian Hipotesis (H2) Pengaruh Kpercayaan Merek Terhadap Keputusan Pembelian

Diketahui nilai sig. untuk pengaruh X2 terhadap Y adalah sebesar $0.041<0.05$ dan nilai t- hitung $2.071>\mathrm{t}$ tabel 1.985, sehingga dapat disimpulkan bahwa H2 dapat diterima dan H0 ditolak. Sehingga dapat disimpulkan bahwa variabel Kepercayan Merek berpengaruh positif dan signifikan terhadap keputusan pemebelian konsumen.

Pengujian Hipotesis (H3) Pengaruh Kualitas Produk Terhadap Keputusan Pembelian

Diketahui nilai sig. untuk pengaruh X3 terhadap y adalah sebesar $0.000<0.05$ dan nilai t- hitung $5.232>$ ttabel 1.985, sehingga dapat disimpulkan bahwa H1 dapat diterima dan H0 ditolak. Sehingga dapat disimpulkan bahwa variabel kualitas produk berpengaruh positif dan signifikan terhadap keputusan pembelian konsumen.

Uji-F

Tabel 5.

Hasil Uji Signifikansi Simultan (Uji - F)

\begin{tabular}{|l|l|r|r|r|r|r|r|}
\hline \multicolumn{1}{|c|}{ Model } & Sum of Squares & df & Mean Square & \multicolumn{1}{c|}{ S } & \multicolumn{1}{c|}{ Sig. } \\
\hline 1 & Regression & 880.020 & 3 & 293.340 & 107.418 & $.000^{\mathrm{b}}$ \\
\cline { 2 - 8 } & Residual & 264.891 & 97 & 2.731 & \\
& Total & 1144.911 & 100 & & & \\
\hline
\end{tabular}

Sumber : Data Olahan

Berdasarkan data tabel di atas diketahui nilai signifikansi untuk pengaruh $\mathrm{X} 1$, X2, dan X3 secara simultan terhadap Y adalah sebesar $0,000<0,05$ dan nilai F - hitung $107.418>$ F- tabel 2.70, sehingga dapat disimpulkan bahwa H4 diterima dan H0 dotolak. Sehingga dapat disimpulkan bahwa variabel Citra Merek, Kepercayan Merek dan Kualitas Produk secara simultan berpengaruh positif dan signifikan terhadap keputusan pembelian konsumen.

Tabel 6

Hasil Uji Koefisien Determinasi $\left(\mathbf{R}^{2}\right)$

\begin{tabular}{|c|c|c|c|c|}
\hline Model & $\mathrm{R}$ & R Square & Adjusted R Square & Std. Error of the Estimate \\
\hline 1 & $.877^{\mathrm{a}}$ & .769 & .761 & 1.653 \\
\hline
\end{tabular}

Sumber : Data Olahan

Berdasarkan data tabel di atas dapat diketahui nilai R Square sebesar 0,769, hal ini mengandung arti bahwa pengaruh X1, X2, dan X3 secara simultan terhadap variabel Y adalah sebesar 76,9\%. Dapat dikatan bahwa semakin kuat modeldalam menerangkan hubungan variabel independen dengan variabel dependen. 
Muh Hasban Wadi, Muinah Fadhilah dan Lusia Tria Hatmanti Hutami, Analisis Pengaruh Citra Merek, Kepercayaan Merek dan Kualitas Produk Terhadap Keputusan Pembelian Sepatu Specs (Studi Kasus Pada Konsumen Sepatu Specs Di Kota Lombok Timur)

\section{Pengaruh Citra Merek Terhadap Keputusan Pembelian Sepatu Olahraga Merek Specs}

Berdasarkan data penelitian diatas, semua pertanyaan pada kuessioner dinyatakan valid setelah dilakukan pengujian kualitas data dengan ketentuan corrected item-total correlation diatas 0.5 dan untuk nilai reliabilitas nilai cronbach's alpha diatas 0.60 , sehingga data dalam penelitian ini dinyatakan reliabel atau handal untuk dijadikan sebagaialat ukur dalam penelitian ini. Pengolahan data yang dilakukan menggunakan IBM SPSS mendapatkan hasil bahwa variabel citra merek memiliki pengaruh yang positif dan signifikan terhadap keputusan pembelian sepatu olahraga merek specs. Semain tinggi citra merek sepatu olahraga merek specs dimata konsumen maka akan semakin tinggi keputusan pembelian sepatu olahraga merek specs. Berdasarkan jawaban konsumen dalam kuesioner sebagian besar konsumen menjawab sangat setuju. Hal ini membuktikan bahwa citra merek sepatu olahraga merek specs sudah memiliki merek yang terkenal, memilikikualitas yang bagus dan mudah diingat oleh konsumen. Citra Merek merupakan salah satu factor yang sangat penting dalam menentukan keberhasilan pemasaran sebuah perusahan. Dimana perusahaan harus membentuk citra merekyang baik untuk mendapatkan pelanggan baru dan untuk mempertahankan pelanggan lama. Hasil ini sejalan dengan penelitian yang dilakukan oleh Amilia \& Asmara (2017) yang melakukan penelitian tentang "Pengaruh Citra Merek, Harga dan Kualitas Produk Terhadap Keputusan Pembelian Hanphone Merek Xiomi Di Kota Lngsa" yang memberikan hasil bahwa Citra Merek berpengaruh positif dan signifikan terhadap keputusan pembelian konsumen.

\section{Pengaruh Kepercayan Merek Terhadap Keputusan Pembelian Sepatu Olahraga Merek Specs}

Dari hasil penelitian diatas, dapat di katakan bahwa setelah dilakukan pengujian kualitas data, semua pertanyaan dalam kuesioner dinyatakan valid dengan nilai Corrected Item-Total Corelation diatas 0.5 dan untuk reliabilitas semua data dalam penelitian ini dikatakan reliabel atau handal untuk dijadikan sebagai alat ukur dalam penelitian ini dengan nilai Cronbach's Alpa lebih dari 0,60. Pengolahan data yang dilakukan menggunakan IBM SPSS mendapatkan hasil bahwa variabel Kepercayaan Merek berpengaruh positif dan signifikan terhadap keputusan pembelian sepatu olahraga merek specs. Konsumen sangatyakin dengan produk sepatu olahraga merek specs karena kualitas dan kehandalan yang dimiliki sepatu olahraga merek specs. Semakin tinggi keyakinan konsumen terhadap produk sepatu olahraga merek specs maka akan semakin tinggi juga keputusan konsumen untuk melakkan pembelian sepatu olahraga merek specs. Berdasarkan jawaban responden yang didapatkan dalam kuesioner bahwa sebagian besar konsumen menjawab sangat setuju. Hal ini mebuktikan bahwa sepatu olahraga memiliki keunggulan yang berbeda dibandingkan dengan sepatu olahraga mrek lainnya yang mebuat konsumen merasa sangan yakin dengan produksepatu olahraga merek specs. Kepercayaan Meek juga merupakan factor yang sangat penting untuk memenangkan persaingan dipasaran diaman perusahaan yang sudah memiliki nama yang baik dimata konsumen dengan kehadalannya akan semakin mudah untuk menadapatkan pelanggan baru dan untuk dapat mempertahankan pelanggan yang sudah ada. Hasil penelitian ini sejalan dengan hasil penelitian yang dilakukan oleh Fauzan et al., (2015) yang melakukan penelitian tentang "Pengaruh Kpercayaan Merek, Periklanan, Dan Kualitas Produk Terhadap Keputusan Pembelian Minuman Isotonik Mizone Di Kota Palu “ dengan hasil penelitian bahwa Kepercayaan Merek Berpengaruh Positif dan Signifikan Terhadap Keputusan Pembelian konsumen terhadap minuman isotonic mizine di kota palu.

\section{Pengaruh Kualitas Produk Terhadap Keputusan Pembelian Sepatu Olahraga Merek Specs}

Berdasarkan data penelitian diatas, bahwa setelah dilakukan pengujian kualitas data, semua pertanyaan dalam kuesioner dikatan valid dengan niali Corected Item- Total Correlation diatas 0.5. Dan untuk reliabilitas semua data dikatan reliabel atau hadal untuk dijadikan sebagai alat ikur dalam penelitian ini dengan nilai Cronbach's Alpha diatas 0.60 . Pengolahan data yang dilakukan menggunakan IBM SPSS menghasilkan bahwa kualitas produk berpengaruh positif dan signifikan terhadap keputusan pembelian sepatu olahraga merek specs. Hal ini membultikan bahwa semakin tinggi kualitas sepatu olahaga merek specs maka akan semakin tinggi juga keputusan konsumen untuk membeli sepatu olahraga merek specs. Kualitas Produk merupakan factor yang sangat penting dalam menentukan keperhasilan pemasaran sebuah perusahaan. Kualitas produk merupakan factor utama yang akan dilihat olehkonsumen sebelum melakukan pembelian. Produk yang memiliki kualitas yang bagus akan cenderung lebih banyak diminati oleh konsumen.produk yang memiliki kualitas yang bagus tentunya akan dapat meningkatkan penjualan. Berdasarkan data jawaban responden dalam kuesioner sebagian besar responden menjawab sangat setuju. Hal ini membuktikan bahwa semakin tinggi kualitas sepatu lahraga merek specs maka akan semakin tnggi keputusan konsumen untuk membeli sepatu olahraga merek specs karena kualitasnya yang bagus. Hasil penelitian ini sejalan dengan penelitian yang dilakukan oleh Desty Wulandari \& Alananto Iskandar (2018) yang melakukan penelitian tentang "Pengaruh Citra Merek dan Kualitas Produk Terhadap Keputusan Pembelian Pada Produk Kosmetik" dengan memberikan hasil bahwa kualitas produk berpengaruh positif dan sigifikan terhadap keputusan pembelian konsumen pada produk kosmetik. 
Muh Hasban Wadi, Muinah Fadhilah dan Lusia Tria Hatmanti Hutami, Analisis Pengaruh Citra Merek, Kepercayaan Merek dan Kualitas Produk Terhadap Keputusan Pembelian Sepatu Specs (Studi Kasus Pada Konsumen Sepatu Specs Di Kota Lombok Timur)

\section{Simpulan}

1. Secara parsial Citra Merek berpengaruh positif dan signifikan terhadap keputusan pembelian sepatu olahraga merek specs. Hal inidi buktikan dengan hasil uji hipotesis dengan nilai signifikansi $t-$ hitung $2.280>t-$ tabel 1.985. sehingga $\mathrm{H} 1$ diterima dan $\mathrm{H} 0$ ditolak.

2. Secara parsial Kepercayaan Merek berpengaruh positif dan signifikan terhadap keputsan pembelian sepatu olahraga merek specs. Hal ini di buktikan dengan hasil uji hipotesis yang menghasilkan nilai signifikansi $\mathrm{t}-$ hitung $2.071>\mathrm{t}-$ tabel 1.985. sehingga $\mathrm{H} 2$ diterima dan $\mathrm{H} 0$ ditolak.

3. Secara parsial Kualitas Produk Berpengaruh secara positif dansignifikan terhadap keputusan pembelian sepatu olahraga merek specs. Hal ini dibuktikan dengan hasil uji hipotesis yang meberikan hasil nilai signifikansi $\mathrm{t}-$ hitung 5.232 $>\mathrm{t}$-tabel 1.985. sehingga $\mathrm{H} 3$ diterima dan H0 ditolak.

4. Secara simultan Citra merek, Kepercayaan Merek dan Kualitas Produk berpengaruh positif dan signifikan terhadap keputusan pembelian sepatu olahraga merek specs. Hal ini dibuktikan dengan hasil uji data secara bersamaan yang memberikan hasil nilai signifikansi $\mathrm{F}-$ hitung $107.418>\mathrm{F}-$ tabel 2.70. sehingga $\mathrm{H} 4$ diterima dan H0 ditolak.

5. Variabel yang paling dominan dalam mempengaruhi keputusan pembelian sepatu olahraga merek specs adalah variabel Kualitas Produk dengan nilai sigifikansi t - hitung 5.232 > t-tabel 1.985.

\section{Daftar Pustaka}

Amilia, S., \& Asmara, M.O.Nst (2017).Pengaruh Citra Merek, Harga, Dan Kualitas Produk Terhadap Keputusan Pembelian Hanphone Merek Xioami Di Kota Langsa. Jurnal Manajemen dan Keuangan, Vol 6, No.1.

Bahar, A. F. (2019). Pengaruh brand image (citra merek) dan kualitas produk terhadap keputusan pembelian produk smartphone Samsung. Skripsi. Tidak Diterbitkan. Fakultas Konsentrasi Bisnis dan Perdagangan Internasional. Sekolah Tinggi Ilmu Ekonomi: Makassar.

Desty Wulandari, R., \& Alananto Iskandar, D. (2018). Pengaruh Citra Merek Dan Kualitas Produk Terhadap Keputusan Pembelian Pada Produk Kosmetik. Jurnal Riset Manajemen Dan Bisnis (JRMB) Fakultas Ekonomi UNIAT, 3(1), 11-18.

Fauzan, M. R., Sutomo, M., \& Mubaraq, R. (2015). Pengaruh kepercayaan merek, periklanan, dan kualitas produk terhadap keputusan pembelian produk minuman isotonik mizone di kota palu. Ilmu Manajemen Universitas Tadulako, 1(1), 7-14.

Farhan, M. Y. (2015). Analisis pengaruh citra merek, kepercayaan merek, dan kualitas produk terhadap keputusan pembelian sepatu nike (studi kasus konsumen nike di kota semarang), Skripsi. Tidak Diterbitkan. Fakultas Ekonomika dan Bisnis. Universitas Diponegoro: Semarang.

Fitriah, N. L., Budiyanto (2020). Pengaruh Kualitas Produk. Promosi dan Kualitas Pelayanan Terhadap Keputusan Pembelian Pada Kedai Friday Kopi Surabaya. Jurnal Ilmu dan Riset Manajemen, Vol 9, Nomor 3. eISSN:2461-0593

Iriani, F., \& Indriyani, R. (2019). Pengaruh Kualitas Produk, Persepsi Harga Dan Citra Merek Terhadap Keputusan Pembelian Sariayu Martha Tilaar.

Jayanti, R. D., \& Putri, S. K. (2019). Pengaruh Citra Merek Dan Kualitas Produk Terhadap Keputusan Pembelian Sepeda Motor Vario. Jurnal Manajemen Dan Bisnis Dewantara, 2(2), 116-123.

Ratnasih, C., \& Nurjananah, S. (2019). Pengaruh Harga dan Kualitas Produk Terhadap Keputusan Pembelian Mie Instan Merek Mie Sedaap Serta Implikasinya Terhadap Loyalitas Pelanggan Di Perumahan Pekayon Bekasi Selatan. Jurnal Mnajemen. Vol 7. No . 2. FE-UB

Sugiyono (2018). Metode Penelitian Manajemen. Bandung : APABETA,cv.

Sutarso, P. J. A., \& Suyanto, A. M. A., (2019). Analisis Pengaruh Kualitas Produk Dan Citra Merek Terhadap Loyalitas Konsumen Pada Marketplace Di Indonesia. e-Proceding Of Management, 6(2), 2355-9357.

Tazkiyatunnisa, M. (2019). "Pengaruh celebrity endorse, citra merek, dan kualitas produk terhadap keputusan pembelian produk kosmetik Maybelline". Skripsi. Tidak Diterbitkan. Fakultas Ekonomi dan Bisnis. Universitas Muhammadiyah Magelang: Magelang.

Trista, N., prihatini, A., \& Saryadi, S. (2013). Pengaruh Citra Merek (Brand Image) Dan Kepercayaan Merek (Brand Trust) Terhadap Keputusan Toyota Avanza Di Kota Semarang. Jurnal Ilmu Administrasi Bisnis S1 Undip, 2(2), 21-28.

Veronika, J., \& 2Hikmah. (2020). Pengaruh Kualitas Produk, Promosi dan Citra Merek Terhadap Keputusan Pembelian Keripik Tempe di Kota Batam. Journal Of Management, Accounting, Economic and Business, 01(02), 1-15. 